\title{
ВСЕСВІТНЯ ІСТОРІЯ
}

УДК 94(450)[323.327:060.13]«13»

DOI: $10.24144 / 2523-4498.1(42) .2020 .202240$

\section{«ДОСІ НЕ БУЛО ТАК, ЩОБ НА ЗБОРИ ПРИЙШЛИ ВСІ...»: МАЙСТЕР І РЕМІСНИЧИЙ ЦЕХ ЗА ДОБИ РАННЬОГО РЕНЕСАНСУ (НА МАТЕРІАЛІ СТАТУТУ ЦЕХУ МАЛЯРІВ С'ЄНИ 1356 р.)}

\author{
Кушнарьова Марія Борисівна \\ кандидат філософських наук, науковий співробітник \\ Національної бібліотеки України імені В. І. Вернадського, м. Київ \\ E-mail: mariakushn8@gmail.com \\ https://orcid.org/0000-0003-3361-8838
}

\begin{abstract}
Основний зміст дослідження становить аналіз тексту статуту иеху малярів С'єни, укладеного у 1356 . У статті подано стислу довідку про історію введення документу до наукового обігу. Історія створення документу розглядається автором в контексті політичної історії C'єни ХIV ст.. Автор висуває припущення, щзо формально статут було укладено для того, щуоб уможливити участь членів цуеху у виборах та управлінні містом. Найбільшою є група статей, котрі регулюють організаційні питання діяльності иеху, різні iї сторони та статус керівників цеху, зокрема, визначено платню, яка призначалася керівникам иеху, обов'язки керівників цеху та його членів. Аналіз статей, котрі регулюють накладання штрафів на членів цеху, дозволяє зробити висновок про те, щуо цех художників С'єни не виконував функиії розробника та регулятора стандартів суто ремісничої та комериійної діяльності. Статут регулював насамперед відносини між майстрами, у той чи інший спосіб пов'язані з виробництвом, точніше, з професійною діяльністю. 3 огляду на ие цеех постає саме як колегія фахівців, яка була зацікавлена у тому, щэоби кожний член иеху міг займатися своєю справою без загрози збитків чи перешкоджань з боку інших членів цеху, а також щоб реноме колегії було незаплямованим, оскільки це реноме, зворотнім чином, генерувало репутацію кожного члена иеху. Автор приходить до висновку, щчо с'єнський иех малярів виконував функиії своєрідної референтної нормативної групи, яка досить чітко визначала права та обов'язки своїх членів, встановлюючи етичні правила та норми, яких вони мали дотримуватися у професійному житті та пов'язаному з ним спілкуванні. Італійський ремісничий иее постає насамперед засобом, щуо уможливлював самоідентифікацію майстра, у такий спосіб великою мірою визначаючи його місие в системі тогочасних соиіальних зв'язків.
\end{abstract}

Ключові слова: ремесло, цеех, статут, місто, С'єна, художник, Ренесанс, Італія.

Постановка проблеми. Важливим джерелом для дослідження історії середньовічного та ренесансного соціуму та економіки є статути ремісничих цехів. Кожний статут, що його зберіг для нас час, вартий спеціальної наукової розвідки, але якісь документи 3 різних причин привертають більшу увагу дослідників, якісь - меншу. Також, 3 огляду на відсутність перекладів, далеко не всі подібні пам'ятки доступні, зокрема, українським науковцям.

Це повною мірою стосується «Breve dell'Arte de'

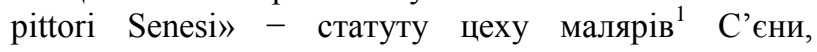
укладеного у 1356 р.. Документ жодного разу не був опублікований українською чи російською мовами, i великою мірою через це майже невідомий вітчизняним дослідникам. Статут гідний масштабного міждисциплінарного дослідження за участі як істориків, так і фахівців 3 історії права,

\footnotetext{
1 Упродовж перебування документу у науковому обігу склалася загальна традиція, відповідно до якої наріжне для Статуту італійське pittori зазвичай перекладається як, наприклад, painter англійською чи «художник» російською. Але, оскільки художники в італійських землях у XIV ст. виконували дуже широкий спектр робіт (про що детальніше йтиметься нижче) та 3 огляду на особливості української лексики, видається за можливе передати тогочасне італійське pittori староукраїнським словом «маляр», котре семантично та історично ближче до італійського терміну.
}

історичної соціології, історичної антропології, історії мистецтва тощо, тому мета цієї розвідки познайомити вітчизняних дослідників з важливою та вкрай цікавою пам'яткою, у такий спосіб, можливо, заохотивши до іiі використання та подальшого вивчення.

У XIV ст. маляри, а, відповідно, й художники у нашому сучасному розумінні, ще не вважалися митцями, тобто особами, наділеними якимись особливими талантами, такими, хто для роботи, на відміну від представників інших професій, потребує натхнення. Тому статут цеху малярів був установчим документом одного 3 багатьох співтовариств осіб, котрі займалися суто ремісничим виробництвом i були суб'єктами цехової організації. Тому ще однією метою пропонованого дослідження є визначення, за допомогою аналізу цього документу, ступеня впливу цеху як на тогочасне виробництво, його кількісний та якісний (змістовний) бік, так і на інші сфери життя майстра-ремісника доби раннього італійського Ренесансу.

Досягненню зазначених цілей сприяє використання методології та підходів, характерних для соціальної історії мистецтва - галузі, представленої, зокрема, відомими працями П. Берка [Burke] та M. Бексендолла [Baxandall], хоча вони присвячені

(c) Кушнарьова М. Б. 
хронологічно пізнішому часу, ніж доба виникнення с'єнського статуту.

Аналіз досліджень та публікацій. Вперше статут був опублікований Гульєльмо Делла Валле у I томі «С'єнських листів» у 1782 р. [Della Valle, p. 143-161]. Видатний знавець-францисканець Делла Валле, хоча й був великим ентузіастом дослідження італійського мистецтва, жив у добу, коли вимоги до публікації історичних документів були несформовані, тому діяв на власний розсуд: текст певної кількості статей він подав відповідно до оригіналу, інші статті - у власному переказі, від інших залишились самі назви.

Цілком професійно, з огляду на реалії першої половини XIX ст. поставився до публікації документу німецький вчений Йоган Гай. У 1839 1840 pp. він видав тритомник джерел 3 історії італійського мистецтва, серед яких у першому томі повний текст статуту с'єнських художників [Carteggio, p. 1-31]. Цікаво, що назва його праці перекладається як «Документи невидані», тобто «такі, що не публікувалися раніше», але у коментарі до статуту він згадує «С'єнські листи» Делла Валле. Гай запроваджує нумерацію і подає оригінальний текст усіх статей.

У тому самому 1840 р. Гай у віці 36 років помер. У 1854 р. Гаетано Міланезі видає документ ще раз [Documenti, 1854, p. 1-51], згадуючи у передмові видання Делла Валле та Гая як важливі віхи на шляху дослідження історії с'єнського мистецтва. Варіанти Гая та Міланезі дещо відрізняються: ст. I (за Гаєм) у Міланезі поділена на дві, тому стт. II-IV у виданні Гая відповідають стт. III-V за Міланезі. Міланезі додає ст. VI «Про платню ректора», якої нема у виданні Гая, відповідно, далі стт. V-XLI у Гая відповідають стт. VII-XLIII у Міланезі, розбіжність у нумерації поширюється також i на статті, додані до початкового тексту у пізніший період (до 1428 р.).

Передбачувано статут цеху малярів С'єни став винятково важливим джерелом з історії насамперед с'єнського мистецтва, тому зверталися до цього документу, посилалися на нього, використовували його, мабуть, усі вчені, котрі, кожний з власною метою, аналізували мистецьке середовище С'єни. Слід згадати хоча би класиків мистецтвознавства M. Miсcа та Е. Карлі, авторів грунтовних праць 3 історії мистецтва С'єни дученто та треченто Д. Норман, Дж. Хук, більш знайомих вітчизняним читачам В. М. Лазарєва та В. П. Головіна.

Але попри помітне прикладне значення, безпосередньо об'єктом грунтовних досліджень, як не дивно, статут чомусь досі не став. Як такий документ привернув увагу хіба що Гейдена Магінніса. У своєму історико-антропологічному дослідженні особливостей побутування та діяльності с'єнських художників XIV ст. він зробив першу та єдину (поки що) спробу здійснити більш-менш грунтовний аналіз статуту 3 огляду на те наукове завдання, яке він для себе виокремив, та подає англомовний переклад статуту, зроблений Г. Еразмі [Maginnis, p. 199-224]. Також окремі аспекти статуту, зокрема, списки майстрів, які в різні часи під ним підписувалися, ставали об'єктом дослідження інших вкрай поодиноких вчених.
Відповідно до пануючої тепер традиції вважається, що до наукового обігу статут введено саме Г. Міланезі. Цієї точки зору дотримується, зокрема, Г. Магінніс [Maginnis, p. 84], саме на видання Міланезі посилається переважна більшість дослідників.

Виклад основного матеріалу. Вже самий час виникнення цього статуту заслуговує на увагу. 3 огляду на італійські, навіть с'єнські реалії, 1356 р. як для появи цехового статуту, - це досить пізно. Найдавніший з відомих тепер міських статутів C'єни - цеху шевців - було укладено у 1219 р. [Barlucchi, p. 521], хоча переважна більшість статутів була укладена в період, що співпадає з правлінням Дев'яти (1287 - 1355), який, почасти завдяки дослідженням та науковому авторитету В. Боускі, вважають часом стабільного розвитку та процвітання міста, своєрідною «золотою добою» С'єни; зокрема, статут цеху шкіряників позначений 1343 р., цеху виробників ключів - 1323, цеху Лана - 1292, найпроблемнішого згодом для міської влади цеху м'ясників - 1288 р. тощо [Statuti senesi]). Втім, факт появи цехових статутів не слід вважати доказом прагнення Дев'яти «демократизувати» міське соціальне та політичне життя: на відміну від Флоренції цехи С'єни в цей період виконували суто дорадчу функцію [Nicholas, p. 259]. Ба більше, політика Дев'яти щодо цехів була жорсткою, аж до випадків оголошення їх поза законом [Bowsky, p. $209-212$ ].

У березні 1355 р. правління Дев'яти закінчилось політичною кризою. У грудні цього року було оприлюднено документ, який, аби запобігти новим заворушенням у місті, передбачав проведення своєрідної реформи цехового устрою та виборчої системи. Документ наказував: «для того, щоб усі співтовариства та народ міста перебували у мирі, (...) аби не допустити незгоди, (...) щоб усі та кожний цехи були зведені лише до дванадцяти головних цехів (ad duodecim capita Artium tantum)» [Documenti, 1906, p. 39]. Кожний такий «головний цех» мав обирати одного пріора, відповідно, у такий спосіб у пріораті прямо чи опосередковано мали бути представлені всі цехи міста.

Цитований документ визначав, хто 3 ким мав об'єднуватися, тобто всі зазначені в документі 63 цехи були чітко розподілені по 12 «головних», які очікувано називалися «L'arte». Ніякого принципу, за яким пропонувалося проводити об'єднання, документ не декларує. Можна припустити, що підставою для розподілу цехів було притаманне тогочасному світогляду уявлення про матеріал (предмет праці) як чинник, що визначав місце ремісника у міжпрофесійній ієрархії. «L'arte del fuoco» (цех вогню) об'єднував, відповідно, ремісників металообробних спеціальностей (ковалі, виробники ножів, ключів тощо, але не ювелірів, ймовірно, через те, що останні мали справу тільки 3 певними матеріалами), а також спільна чи близька сфера діяльності (наприклад, до «L'arte de'Carnaiuoli» (цеху м'ясників) мали належати м'ясники, торговці вином, власники постоялих дворів, торговці худобою, дичиною, овочами [Documenti, 1906 p. 44-45]). Також, можливо, 
бралися до уваги суто кількісні міркування, зокрема, шевців об'єднали 3 coiarii (виробниками шкіряного одягу на кшталт колету), ймовірно, на підставі того, що ці цехи працювали 3 одним i тим самим матеріалом, але тільки з ними, ймовірно, через те, що в ті часи, як відомо, шевці були мало не найчисленнішою спеціальністю.

Малярі потрапили до цеху «деревообробників» (L'arte di Maestri del legname) разом з каменотесами, арбалетниками, виробниками меблів, токарями та бондарями [Documenti, 1906, p. 44-45]. Мабуть, міські законодавці керувалися тим, що малярі використовували для роботи поверхні дошок чи/та стін.

В грудні 1355 р. було оголошено реформування цехового устрою, а у березні 1356 р., тобто, менше ніж за три місяці, малярі уклали статут. Можна припустити, що перспектива об'єднання прискорила процес оформлення документу. Так само можна припустити, що автори поспішали, цим можна пояснити очевидну фрагментарність статуту та повторення деяких статей, що неодноразово зауважували дослідники. Ймовірно, мала місце своєрідна кодифікація, тобто зведення до єдиного документу норм, які вже давно діяли, існуючи на звичаєвому рівні. Це відповідало традиції, яка на той час панувала, відповідно до якої цехові статути були «фіксацією старих норм цехового права, що складалися поколіннями і цехові організації виникали завжди набагато раніше, ніж писане цехове право» [Стоклицкая-Терешкович, с. 83]. Непрямо це підтверджує згаданий Г. Магінніс, котрий вважає, що якісь співтовариства художників існували у С'єні вже у 60-х pp.. XIII ст.. [Maginnis, p. 90], хоча важко зрозуміти, на чому він грунтує це твердження.

Тому, можливо, правильніше вважати 1356 р. не часом виникнення цеху малярів С'єни, а часом оформлення його статуту, тобто часом інституціалізації цехової організації с'єнських малярів.

На особливу увагу заслуговує те, що, на відміну від статутів аналогічних цехів інших італійських міст (Флоренція, Падуя тощо), с'єнський статут укладено італійською мовою, або, як тоді висловлювалися, на volgare. А. Барлуччі вважає це проявом суто c'єнського явища i називає його «l'ideologia del volgare». Сутність його полягає у тому, що нормативні документи в місті вже наприкінці XIII-на початку XIV ст. складалися у двох редакціях латинською та volgare, на відміну від попереднього періоду дученто, коли офіційні папери складалися виключно латинською. Барлуччі справедливо вважає це проявом потужних політико-ідеологічних процесів, які вплинули не тільки на статути ремісничих цехів, а й на всю громадську документацію [Barlucci, p. 529 - 530]. Важливим етапом цієї «l'ideologia del volgare» стало укладення саме на volgare с'єнської Конституції 1309 - 1310 pp.

Статут цеху малярів C'єни (за виданням Міланезі) складається 361 статті, 3 яких I-XLIII належать до першого, початкового варіанту статуту, затвердженого у лютому 1355 р. (1356 р. за сучасним календарем). Статті XLIV-LXI були додані пізніше: 5 (стт. XLIV-XLVIII) - y 1359 p., 1 (XLIX) - y 1361 p., 5 (L-LIV) - y 1367 p., 1 (LV) - y 1370 p., 6 (LVI-LXI) - у 1428 р. Зважаючи на таку істотну розтягненість у часі процесу формування документу, найдоцільнішим i найкоректнішим видається здійснення спроби аналізу початкової частини, що формувалася як цілісний документ, принаймні, мала би такою бути.

Наявні у першій редакції статуту 43 статті можна умовно поділити на кілька груп, виходячи 3 тієї галузі життя цеху та його членів, якої вони стосуються.

Найбільшою є група статей, котрі регулюють організаційні питання діяльності цеху, різні іiі сторони та статус керівників цеху.

Відповідно до ст.IV керівництво цехом здійснювали ректор (rectore), скарбник (camarlengo) та три радники (consiglieri). Це відповідає загальнос'єнській традиції, оскільки саме так називалися відповідні посади в статутах інших цехів міста.

Заробітна платня ректору встановлювалася у $20^{1}$ сольді ${ }^{2}$ на 6 місяців, скарбнику - 15 сольді (VI). Цех наймав вісника, який отримував 5 сольді, за виконання конкретного доручення - 2 денарі, при цьому він мав право працювати «за сумісництвом», тобто виконувати доручення осіб, які не належали до цеху, але мав брати за це по 4 денарі (VII). Відповідно до ст.V ректор мав упродовж 15 днів після власного обрання скликати загальні збори (raccolta generale) i далі скликати збори за потребою (XXIII), а член цеху, якщо його викликали на збори, повинен був з'явитися під загрозою штрафу (XXX). Для коригування статуту ректор мав призначити двох чи трьох «кращих мужів» (buoni huomini) (XXIV). Ректор мав виступати як миротворець, сприяючи залагодженню сварок та вирішенню суперечок, що виникали між членами цеху (XIX), також він мав проводити розслідування щодо тих, хто порушив чи задумав порушити статут (contrafacesse overo commettessero alcuna cosa contra lo statuto) (XXXVIII). Скарбник цеху не мав права накладати штрафи всупереч статуту (XXI).

Перед закінченням терміну повноважень ректор мав надати звіт (XX). Після обрання нових керівників цеху обиралися також і три синдики, які повинні були ретельно перевірити діяльність попередніх керівників і ознайомити всіх зі своїми висновками упродовж 15 днів після виборів (XXIX).

Члени цеху своєю чергою повинні були надавати допомогу ректору у виконанні його обов'язків (XLI), не суперечити віснику ректора (XXII), не розголошувати таємної інформації, наданої ректором (XLII), не вести розмов, які ганьблять ректора (XVIII), не завдавати збитків цеху чи його керівникам (XXXIII, XXXIX, XLIII).

Останні зі згаданих статей деталізують розуміння тогочасними ремісниками цеху як своєрідної форми

\footnotetext{
${ }^{1}$ У тексті статуту грошові суми, зрозуміло, позначені римськими цифрами.

${ }^{2}$ У XIV ст. 12 с'єнських денарі дорівнювали 1 сольді, 20 сольді - 1 лірі.
} 
об’єднання. Ці три статті присвячені особливостям реалізації однієї й тієї самої моральної норми, яка вимагала, щоб «ніхто не казав чи робив чи задумував» робити нічого «проти згаданих цеху та спільноти (contro l'arte et università predecta) [Documenti, 1854, p. 13], чи «проти честі та блага та становища згаданих цеху та спільноти», але, якщо ст. XXXIII порушення цієї норми карає штрафом у 40 сольді, то ст. XXXIX додає до штрафу моральне покарання у вигляді скликання зборів для розгляду вчинку [Documenti, p. 16]. У ст. XLIII, натомість, йдеться про діяння чи висловлювання, що можуть завдати шкоди цеху (decta arte) чи статуту, але не згадується про «спільноту» (università). Можливо, саме тому це карається штрафом лише у 10 сольді, втім, за ректором визнається право зменшувати чи збільшувати цю суму, виходячи зі становища винного та тяжкості його провини.

Насамперед слід звернути увагу на вислів «цех та спільнота» (l'arte et università). Цех як інституція та спільнота як співтовариство колег, тобто майстрів, зайнятих однією (хоча зазвичай не спільною!) справою, не були тотожними чи навіть взаємозамінними у сприйнятті тогочасних ремісників, що нагадує особливості вживання в ті часи слів «сіttà» та «comune», які, так само як i зазначені «arte» та «università», позначали поняття, абсолютно не взаємозамінні у свідомості тогочасних італійців. Цех (l'arte) у житті майстра виконував функції інституціонального середовища інкорпорації, яке, забезпечуючи його членством у певній групі, уможливлювало вибудовування ним своєї соціальної ідентичності [Гнатенко, Павленко, с. 67]. Спільнота (università), зв'язки всередині якої мали переважно особистий характер, була чинником визначення морально-етичного буття особи. Відповідно, завдати образи цехові значило образити ремесло, фах, справу, $\mathrm{i}$ це стосувалося кожного окремого майстра як представника цього ремесла чи фаху. Образа спільноти була образою всіх членів цеху, тобто була образою кожного майстра як члена цієї спільноти. Можливо, саме тому у ст. XV йдеться про покарання за розголошення таємниць саме спільноти (università) [Documenti, 1854, p. 7], тобто, таємниць не професійного чи виробничого змісту, а таких, що стосуються особистостей членів спільноти та стосунків між ними, тобто тієї галузі, яку ми тепер вважаємо корпоративною етикою.

Саме цього боку існування цеху стосується ст. III, що зобов'язує майстрів віддавати шану померлим товаришам за цехом та у випадку смерті певних категорій родичів членів цеху (батько, мати, дружина, син, брат, рідний племінник, двоюрідний брат 3 боку батька. Ректор повинен був послати вісника до членів цеху, які повинні були забезпечити присутність «однієї чи двох осіб від майстерні» в залежності від статусу небіжчика [Documenti, 1854, p. 2]). Схожі за змістом статті наявні у статутах, мабуть, усіх цехів тогочасних італійських міст. Cт. XXVI призначає покарання за відмову від посади, на яку майстра обрали члени цеху, тобто за нехтування довірою та думкою колег.
Стаття XXVII карає штрафом невиконання обов'язку несення свічі під час процесії на свято покровителя малярів-художників св. Луки. За ст. I нести свічу «власним коштом» повинні були не тільки майстри-члени цеху, але також і працівники, яких наймали на рік, на місяць, на день або для виконання певного замовлення чи певної роботи ${ }^{1}$. Ставилися до цього вочевидь дуже серйозно: відповідно до тієї самої статті ректор мав за вісім днів до свята скликати збори, аби визначити, хто несе подвійні свічки (doppieri, тобто канделябр на дві свічі або велика свіча подвійної ваги).

Як відомо, процесії були неодмінною частиною життя тогочасного міста. Вони влаштовувалися 3 нагоди релігійних свят або певних видатних подій, наприклад, у історії С'єни особливої важливості та слави зажила процесія 3 нагоди перенесення алтарного образу Дуччо «Маеста»у у 1311 р. В таких процесіях брали (чи могли брати) участь усі мешканці міста включно 3 жінками та дітьми. Натомість у процесії з нагоди свята покровителя цеху участь брали члени цеху. Тому така процесія була нагодою насамперед усім разом символічно звернутися до святого з проханням про підтримку та захист, а також продемонструвати всьому місту не тільки значення свого фаху, а й заявити про себе як про консолідовану силу, тобто це був своєрідний акт самоствердження та самоідентифікації певної групи. Відповідно, небажання нести свічу з іншими членами цеху (cogli altri), тобто самоусунення від участі у цій події можна було розцінити як спробу руйнування єдності, прояв небажання бути часткою (чи бути сприйнятим як частка) не тільки й не стільки професійної, скільки світоглядної спільності. Ймовірно, саме тому особа, яка, не маючи на те поважної причини, не несла свічу, за ст. I, мала сплатити штраф, а також все одно пізніше принести до церкви св. Луки свічу вагою 1 лібра ${ }^{2}$ [Documenti, 1854, p. 2].

Інші свята перебували в зоні особливої уваги укладачів статуту як привід продемонструвати ревне дотримання членами цеху релігійних норм і звичаїв, але також як джерело підстав не працювати. Крім згаданих вище статей, свят стосуються ще декілька. Ст.XXXVI перераховує всі 57 свят, в які статут цеху забороняв працювати (стт.II та X), а також побіжно згадує «свята, призначені консулами» (Мерканції, М.К.), до них ст.XXXV додає ще два святкові дні, коли робота могла бути припинена за наказом ректора цеху - канун Великодня та Благовіщення. Додавши до цієї кількості неділі (чи працювали художники у суботу - питання невирішене [Maginnis, p. 87]), можна вирахувати кількість робочих днів на рік - приблизно 250 (Магінніс нарахував 242) [Maginnis, p. 87], що відповідає п'ятиденному чи, можливо, навіть чотириденному (за умови неробочих субот) робочому тижню. Але слід пам'ятати, що в С'єні, як і в інших тогочасних італійських містах, поширеною була практика

\footnotetext{
${ }^{1}$ На такі різні терміни працевлаштування звернув увагу Г. Mariнніс [Maginnis, p. 88-89].

${ }^{2}$ Мipa ваги (libra чи libbra), дорівнює приблизно 0, 34 кг.
} 
припинення роботи за наказом міської влади з нагоди якихось спеціальних подій, як радісних (звістка про сприятливі для міста новини, приїзд до міста якогось особливо важливого гостя, тощо), так і сумних (вуличні заворушення різноманітного походження, смерть якоїсь видатної людини тощо), через що тогочасні хроніки рясніють висловами «майстерні позакривалися». Тому насправді робочих днів було ще менше.

Осібно стоїть стаття XXV, яка карає неправдиве свідчення. Оскільки наявність статті свідчить про факти вчинків, що цією статтею каралися, то непрямо це свідчить про «нешляхетні» настанови та звичаї малярів, за якими в ті часи, на відміну від осіб знатного походження чи високого статусу, визнавалася здатність вдатися до брехні.

Чотири статті визначають окремі сторони роботи майстрів, а саме: стт. IX і XII стосуються порядку розгляду скарг, а ст. XI - іноземців, котрим надавалося право працювати в місті за умови сплати 1 флорина (показовим є те, що це - єдиний у статуті випадок використання флорину і він пов'язаний 3 іноземними, тобто нес'єнськими майстрами) та надання застави у 25 лір.

У ст. XXXII і тільки в ній, єдиній у всьому статуті, йдеться про учня у майстерні, а саме, про те, що не можна тримати учня, якщо він не зареєстрований цехом. Втім, «abbia giurato», яке Г.Магінніс подає як «бути зареєстрованим», може також означати «поклястися, дати клятву». 3 одного боку, можливо, це одне й те саме, тобто, відповідно до тодішніх звичаїв «дати клятву» й означало «зареєструватися». 3 іншого боку, на відміну від венеційської традиції, де текст клятви (чи присяги) майстра при вступі до цеху наводиться у статуті [Венецианский цех, с. 6-11], у текстах с'єнських статутів його нема. Це може свідчити або про те, що майстри в C'єні клятву не давали, або про те, що іiі текст був настільки відомий усім, кого це могло стосуватись i/або був достатньо коротким, що фіксувати текст спеціально не було потреби.

Ще чотири статті регулюють випадки порушень виробничої етики, зокрема, карають спроби перебивання роботи в іншого майстра (VIII), переманювання працівників у іншого майстра (XVII), винаймання майстерні на себе, якщо є компаньйон (XXXI), а ст. XIV визначає покарання за спроби маляра шахраювати 3 фарбами, точніше, 3 пігментами, які тоді використовували для виготовлення фарб. Стаття заслуговує на особливу увагу, тому варто навести іiі повний текст:

«Також наказуємо, щоб ніхто з цеху малярів не насмілювався і навіть не мав наміру під час роботи накладати інше золото чи срібло чи інші кольори замість тих, які він пообіцяв, наприклад, золото розбавлене замість чистого золота, олово замість срібла, німецьку лазур замість ультрамарину (azzuro de la Magna per azzuro oltramarino), блакить чи індиго замість лазурі (biadetto overo indico per azzuro), червону охру чи сурик замість кіноварі (terra rossa o minio per cinabro), a хто зробить всупереч зазначеному, буде покараний та присуджений щоразу до сплати 10 лір» [Milanesi, p. 7].
Ультрамарин був найдорожчим у ті часи пігментом, що вироблявся у складний спосіб з ляпіс лазурі, яку видобували на території сучасного Афганістану. В основі німецької лазурі і блакиті були сполуки міді, індиго отримували з рослини, відомої як вайда фарбувальна, яка росла (i тепер росте) по всій Європі. Це були пігменти місцевого виробництва, відповідно, істотно дешевші. Вони давали фарбу схожого темно-блакитного кольору, але поціновувачі відрізняли глибину та насиченість властивого виключно ультрамарину відтінку. Схожим було становище 3 пігментами червоних кольорів: суриком свинцевим та залізним або вохрою, тобто порівняно дешевими пігментами мінерального походження, часто-густо заміняли (або підміняли) кіновар - дуже дорогий пігмент, який виготовляли з украй рідкісної на той час ртуті і який надавав фарбі насиченого благородного відтінку.

Ультрамарин, який майстри тоді використовували для зображення насамперед мафорію Діви Марії, був об'єктом особливої уваги замовників та їхнього прискіпливого ставлення, внаслідок чого він оплачувався окремо, або надавався замовником, або чітко вказувалася ціна пігменту, який художник мав використовувати [Baxandall, pp. 8-11]. Схожим був статус кіноварі. Зрозуміло, що деякі недобросовісні та чапкі на руку майстри користалися 3 цього, підміняючи дорогі оплачені замовником пігменти істотно дешевшими, привласнюючи різницю. Цех, дбаючи про добре ім'я ремесла, намагався у такий спосіб контролювати своїх членів.

Крім останніх згаданих статей, всі інші могли би належати до статуту будь-якої іншої ремісничої спеціальності. Загалом це відповідає традиції, що іiі зауважили дослідники, згідно 3 якою «статути ... рідко стосуються особливостей певного ремесла. Більшість може служити представникам як одного ремесла, так й іншого» [Goldthwaite, p. 251]. Але навіть 3 огляду на це статут с'єнських малярів $\epsilon$ винятком, адже тогочасні статути інших с'єнських цехів приділяють значно більше уваги професійній специфіці. Зокрема, з 78 статей статуту цеху шевців дотичними особливостям праці шевців $є 28,347$ статей цеху виробників ключів - 6 [Statuti senesi, II, 41-245], з 94 статей цеху ювелірів - 19 (статут було укладено у 1361 р.) [Milanesi, pp. 57-104].

Ймовірно, така «неувага» статуту до особливостей праці малярів пов'язана 3 великою різноманітністю сфер застосування їхньої праці та, відповідно, виробленого ними продукту, адже, на відміну від шевців, які робили взуття, чи виробників ключів, тогочасні малярі, крім написання картин чи образі̀в та розписування стін громадських, культових чи приватних будівель фресками, також на замовлення окремих осіб чи міської влади розписували карроччо, прапори, щити, балдахіни, корогви, навіть плащі, створювали обкладинки книг, зокрема, Biccherna (щорічне видання фінансових документів міста), виготовляли декоративні панелі для оздоблення кімнат і меблів (ліжок, скринь (касоне)), інші ужиткові речі (таці), розробляли візерунки-шаблони для мережива тощо. Регулювати весь потенційний спектр діяльності майстра вочевидь 
було неможливо, тому укладачі статуту сконцентрували увагу на аспекті, який був основоположним для праці маляра та водночас найспокусливішим для їхнього сумління, тобто таким, що найлегше надавався до порушень використанні фарб.

Велике різноманіття сфер застосування праці художників спричинило їхню певну спеціалізацію, що знайшло відображення у ще кількох незначних, але цікавих проявах у статуті професійної специфіки, a саме, згадці про «майстрів майстерень та стін» (maestri de le bottighe e de le mura) (XI), тобто, як ми би тепер сказали, майстрів станкового та монументального живопису, та згадці у статті VIII про «художників фігур чи гербів, чи стін» (dipintore di figure o d'arme o di mura). «Художників гербів» можна, за сучасною термінологією, вважати представниками декоративно-ужиткового мистецтва. Це уточнення свідчить про те, що, по-перше, попит на художньо оздоблені ужиткові речі був високим, отже, живопис «просочував» різні сторони життя та побуту тодішньої людини.

Для того, аби члени цеху дотримувалися зафіксованих у статуті норм, застосовувався чинник штрафів. Усі зазначені в статуті порушення крім несплати вчасно штрафів, про що йтиметься нижче, каралися штрафами від 5 сольді до 25 лір ${ }^{1}$.

Найменшу суму - 5 сольді - майстер повинен був сплатити, якщо він не віддав належну шану померлому члену цеху (III), не з'явився на збори членів цеху за викликом ${ }^{2}$ (XXX) та всупереч забороні працював у переддень Великодня чи Благовіщення (XXXV).

10 сольді сплачував майстер за те, що він не ніс свічу на свято св. Луки (I), працював у свято (II), суперечив посланцю ректора (XXII), порушував статут (XXXVII), завдав образи цеху (XLIII). Також 10 сольді мав сплатити ректор, якщо він не скликав збори, коли у цьому була потреба (XXIII).

Штрафом у 20 сольді каралася участь у голосуванні, якщо особа, за яку член цеху голосував, була йому родичем чи компаньйоном (XVI), або якщо член цеху сказав щось, що зганьбило ректора цеху (XVIII) або піддав розголосу таємну інформацію, надану йому ректором (XLII). Також цю суму мав сплатити скарбник цеху, якщо він накладав штрафи всупереч статуту (XXI).

Штрафом у 40 сольді (2 ліри) каралося завдання образи цеху (XXXIII). Цю саму суму мав сплатити майстер, який взяв на роботу майстра-іноземця, якщо останній не виконав певні обов'язкові дії (XI). Також цю суму повинен був сплатити ректор, якщо він у 15

\footnotetext{
${ }^{1}$ Середня денна платня найманого працівника в C'єні на той час складала 4 сольді, хоча муляри отримували 15 та більше [Balestracci, p. 119]. Дуччо, за контрактом на «Maestà» - твір, що став знаковим для С'єни, - отримував 16 сольді на день (у 1308 р.) [Kleiner, p. 506]. Цікаві дані про тогочасні ціни на продукти харчування та заробітну платню представників різних професій наводить Д.Балестраччі [Balestracci], а про доходи італійських художників, щоправда, дещо пізнішого періоду - XV ст.. - В. П. Головін [Головин, 2000].

${ }^{2}$ Неявка на збори громадського органу за викликом взагалі каралася штрафом, зокрема, за це свого часу (у 1289 р.) покарали Дуччо [Ross, p. 111].
}

днів по своєму обранні не скликав загальних зборів членів цеху (V). Ця сама сума була базовою при визначенні штрафу, який накладався на ректора та/чи скарбника, якщо синдики доходили висновку, що ці особи припустилися порушень статуту під час перебування на посадах (XXIX).

Штрафом у 60 сольді (3 ліри) каралося неправдиве свідчення (XXV).

Штрафом у 5 лір каралася відмова від посади, на яку майстра обрали члени цеху (XXVI), винаймання майстерні на себе у випадку наявності компаньйона (XXXI) та розголошення таємниць цеху (XV).

Штрафом у 10 лір каралося перебивання роботи у іншого майстра-члена цеху (VIII) та згадане вище шахраювання з фарбами (пігментами) (XIV).

Найбільший штраф у 25 лір мав сплатити член цеху, який переманив працівника у іншого майстра (XVII).

На перший погляд, спостерігається своєрідна невідповідність між співвідношенням кількості статей, що стосуються певних сторін праці та життя майстра та розмірами штрафів, якими карали те чи інше порушення. Переважна кількість статей, як зазначено вище, присвячена регулюванню організаційно-корпоративного боку діяльності цеху, а кількість статей, що стосуються суто виробничих питань, $є$ дуже невеликою. Натомість штрафи, призначені, наприклад, за працю у свято, неналежне ставлення до смерті колеги чи його певних родичів, відсутність особи на зборах або нехтування обов'язком нести свічу на свято св. Луки, тобто за позавиробничу поведінку, невідповідну зазначеним у статуті нормам, є найнижчими. Найбільші штрафи призначено якраз за порушення суто виробничої етики, причому це $\epsilon$ порушення, спричинені жадібністю, точніше, зажерливістю. Відомо, що зажерливість як така вважалася одним з найтяжчих гріхів. В основі вчинків, що каралися найбільшими штрафами у 10 та 25 лір (перебивання роботи в іншого майстра, шахраювання, переманювання працівника), лежить саме спричинене зажерливістю нехтування нормами професійної моралі, які на той час уже були усталеними, зневажання сутнісних засад існування ремісничого товариства та, у випадку шахраювання, ганьба фаху в очах клієнтівзамовників, тобто не-художників (аутсайдерів - у термінах антропологіï). По суті, останнє є згаданим у ст. XV розголошенням внутрішніх цехових таємниць, але таємниць, що вкривають соромом усю цехову спільноту. У випадку переманювання працівника винуватець ще й штовхав на порушення іншу особу.

Також доволі показовою є стаття, котра призначає порівняно великий штраф за відмову від посади (XXVI). Як слушно зауважив Г. Магінніс, це означає, що такі випадки були [Maginnis, p. 85] i, мабуть, вони були непоодинокі.

На особливу увагу заслуговують статті XXXIX та XL. Стаття XXXIX до покарання того, хто завдав образи «цеху чи спільноті» словом або ділом додає ще одне покарання, зобов'язавши ректора на зборах публічно викрити винуватця, піддавши розголосу його вчинок та «заборонивши» (divetare) його. Стаття $\mathrm{XL}$ наказує, що якщо член цеху не заплатив вчасно 
штраф, призначений ректором чи не скорився волі ректора, то «усім іншим художникам забороняється мати справу 3 цим «забороненим» (devietato), приймати його у своєму помешканні, працювати 3 ним разом у будь-який спосіб» [Documenti, 1854, p. 16].

Сама наявність вимоги «заборони» (з подальшим позбавленням спілкування, отже, символічним вигнанням зі спільноти) споріднює статут ${ }^{1} 3$ істотно давнішими документами, причому насамперед тими, що регулювали монастирське життя (Статут св. Бенедикта, Regula communis) ${ }^{2}$ [Diaz, p. 355]. Як відомо, у такий спосіб спільнота убезпечувала себе від шкідливого впливу та сорому, спричиненого діями особи, що порушила правила. У професійного консорціуму, яким, за сучасною термінологією, можна вважати ремісничий цех, було насправді небагато важелів впливу на поведінку своїх членів і тому виключення зі спільноти ставало «граничною санкцією, покаранням від імені професійного етосу, наділеним великим пафосом» [Скворцов, с. 292].

На жаль, з тексту статуту не можна зрозуміти, ця «заборона» була тимчасовою чи безповоротною. Так само важко зрозуміти, чи була ця «заборона» аналогом вигнання $з$ цеху. Навіть якщо відповісти на останнє питання ствердно, «заборона», про яку йдеться, не означала для особи, яку було покарано у такий спосіб, зміни місця проживання чи перебування, як у випадках виключення 3 монастирської спільноти чи надзвичайно поширеної у ті часи в італійських землях практики вигнання 3 міста окремих осіб чи навіть цілих родин чи родів. До того ж, ступінь спричинених цією забороною емоційних та моральних страждань покараної особи $є$ дискусійним.

3 огляду на викладене, ремісничий цех, принаймні, у XIV ст. в італійських землях, не постає як регулятор виробництва, зокрема, його якісного боку, як це стверджував П. Берк [Burke, p. 67]. Можливо, саме те, що цех малярів С'єни не виконував функції розробника стандартів суто ремісничої та комерційної діяльності своїх членів, та наглядача за їх дотриманням, спричинило відповідне ставлення майстрів до цеху. Це ставлення опосередковано відобразилося у тексті статуту: у ст. XLVII, доданій у 1358 р., укладачі зазначають, що «досі ніколи не було так, щоби на зборах були присутні всі» [Documenti, 1854, p. 19]. Згадана вище очевидна непоодинокість випадків відмови від посади свідчить про те, що художники не горіли бажанням керувати об'єднанням своїх колег, мабуть, надаючи перевагу суто професійній діяльності чи відпочинку. Це набуває особливої виразності на тлі численних відомих свідчень флорентійських купців, котрі, навпаки, дуже пишалися керівними посадами в цеху, які обіймали вони чи їхні родичі (Дж. Мореллі, Б. Пітті, інші). На відміну від них, с'єнські малярі

${ }^{1}$ Схожі норми є у статуті с'єнських шкіряників (стт. XXXVIII, LVIII) [Statuti senesi, II, pp. 305; 318], але відсутні, наприклад, у статуті виробників ключів.

${ }^{2}$ Цікаво, що у згаданих документах в подібних випадках теж акцентуються норми колективного рішення про вигнання та ступінь публічності, тобто розголосу в межах спільноти. згуртованими не були, не відчуваючи особливої потреби у цьому, i тому ставилися до цеху прохолодно.

Навіть такий дуже стислий аналіз пропонованого документу дозволяє зробити певні висновки. Один 3 них - зокрема, про те, що цеховий контроль праці маляра-художника, тобто, як ми сказали би тепер, його творчості, обмежувався лише забороною шахраювання 3 фарбами (з пігментами) та праці на свята, причому останнє $є$ нормою, типовою для всіх тогочасних статутів ремісничих цехів. Якщо взяти до уваги, що с'єнські майстри, так само як їхні колеги 3 інших італійських міст, часто ставали до роботи в інших містах, то ступінь впливу цеху на професійну діяльність майстра чи, як ми тепер це називаємо, творчий процес, стає украй мінімальним. С'єнський цех тут не $є$ винятком, те саме можна сказати і про флорентійський. Це дозволяє стверджувати, що, принаймні, у XIV ст. в італійських землях цех не був чимось на кшталт гальма чи прокрустового ложа, що стримувало творчі поривання та індивідуальність митців.

Очевидно, що статут регулював не виробництво, а відносини між майстрами, що підтверджує думку Д. Харитоновича про те, що «головне завдання цеху - регулювання не виробничих, а людських стосунків» [Харитонович, с. 119]. 3 іншого боку, об'єктом регулювання $є$ переважно людські стосунки, у той чи інший спосіб пов'язані 3 виробництвом, точніше, з професійною діяльністю.

Це уточнення $\epsilon$ важливим 3 огляду на подане вище зауваження, що члени цеху займалися однією й тією самою, але не спільною справою. Справа була в кожного своя. Тому цех постає, як зазначено вище, саме як «професійний консорціум», колегія фахівців, а не «спільнота однодумців», «братство», «родина» тощо. Ця колегія фахівців була зацікавлена у тому, щоби, по-перше, кожний член цеху міг займатися своєю справою без загрози збитків чи перешкоджань з боку інших членів цеху, по-друге, щоб іiі, тобто колегії, реноме в очах «аутсайдерів» було високим і незаплямованим, оскільки це реноме, зворотнім чином, генерувало репутацію кожного члена цеху.

Вище було висловлено припущення, що формально статут було укладено для того, щоб уможливити участь членів цеху у виборах та управлінні містом, тобто С'єною. Подальший перебіг подій показав, що це було цілком реальне завдання. Наслідками його реалізації стало те, що малярі, як і представники інших професій, що передбачали ручну працю та належали до popolo minuto - ковалі, теслі, муляри, - не тільки мали можливість бути обраними, а й справді у помітній кількості обиралися на різноманітні міські посади. Зокрема, у 1368 р. серед осіб, котрі вважалися правоможними обіймати посади в органах міської влади, були 46 шевців, 19 теслів, 17 ювелірів тощо, а також 16 малярів [Wainwright, p. 123].

Висновки. Отже, с'єнський цех малярів створювався не з метою регулювання виробництва. Цех - у реаліях XIV ст. - насамперед виконував функції своєрідної «малої групи» (А. Я. Гуревич), яка формувала коло товаришів, колег, котрі володіли 
одними й тими самими професійними навичками, мали схожий життєвий шлях, вирішували схожі професійні завдання, мешкали в одному місті, були громадянами однієї комуни тощо. Це було те середовище, в якому та з огляду на яке слід було дбати про власне добре ім'я. Відповідно, цех був своєрідною референтною нормативною групою, яка досить чітко визначала права та обов'язки своїх членів, встановлюючи правила та норми, яких вони мали дотримуватися у професійному житті та пов'язаному 3 ним спілкуванні. Італійський ремісничий цех постає насамперед засобом, що уможливлював ідентифікацію, точніше, насамперед, самоідентифікацію майстра, у такий спосіб великою мірою визначаючи його місце в системі тогочасних соціальних зв'язків.

\section{Список використаних джерел}

Balestracci, D., 1975 - 76, «Li lavoranti non cognosciuti». Il salariato in una città medievale (Siena 1340 - 1344), Bulletino senese di storia patria, 82-83, pp. 67-157.

Barlucchi, A., 2013. Gli statuti delle arti e la normativa sul mondo del lavoro nella Toscana dei Comuni: sguardo panoramico e prospettive di ricerca, Archivio Storico Italiano, vol. 171, № 3 (637), luglio-settembre 2013, p. 509-541.

Baxandall, M., Painting and Experience in Fifteenth Century Italy, Oxford Unversity Press, 1972, 165 p.

Bowsky, W. M., 1981. A Medieval Italian Commune: Siena Under the Nine, 1287 - 1355, Univ. of Calif. Press, 1981,327 p.

Burke, P., The Italian Renaissance. Culture and Society in Italy, Princeton Univ. Press, 1994, 287 p.

Carteggio unedito d'artisti dei secoli XIV, XV, XVI, 1840. Pubblicato ed illustrato con documenti pure inediti dal dott. Giovanni Gaye, т. II. Firenze: Molini.

Della Valle, Guglielmo., 1782. Lettere sanesi sopra le belle arti. 3 T. Venezia, Pasquale, 1782, т. I, 292 p.

Dìaz, P. C., 2001, Monasteries in the peripheral area. Topographies of Power in the Early Middle Ages. Ed. by M.B. de Jong, F.Theuws, C. van Rhijn. BRILL, pp. 329-359.

Documenti per la storia dell'arte senese, raccolti ed illustrati dal dott. Gaetano Milanesi, 1854. T. I, Secoli XIII e XIV, Siena: O. Porri, $392 \mathrm{p}$.

Documenti per la storia dei rivolgimenti politici del commune di Siena dal 1354 al 1369, da Giuliano Luchaire, Lyon-Paris, 1906, $272 \mathrm{p}$.

Goldthwaite, R. A., 1982. The Building of Renaissance Florence, John Hopkins University Press, 459 p.

Kleiner, F. S., 2009. Garder's art through the ages: A Global history. Cengage Learning EMEA, 1088 p.

Maginnis, H. B. J., 2003. The World of the Early Sienese Painter, Pennsylvania State University Press, 440 p.

Nicholas, D. M., 2014. The Growth of the Medieval City: From Antiquity to the Early Fourteenth Century, Routledge, 432 p.

Ross, L., 2003, Artists of the Middle Ages. Greenwood Publishing Group, 182 p.

Statuti senesi scritti in volgare ne' secoli XIII e XIV, 1863. Per cura di F.-L. Polidori, Bologna, Romagnoli, V. I-II.

Wainwright, V., 1987. The testing of a popular Sienese regime: The "Riformatori" and the insurrections of 1371, I Tatti Studies in the Italian Renaissance. Vol. 2, pp. 107-170.

Венецианский цех в XIII-XV вв., 1971. Уч. пособие. Ч. 1. Горький: Горьковский гос. ун-т, 24 с.

Головин, В. П., 2000, Цены на произведения искусства в Италии и благосостояние художников, Итальянский сборник.

Сб. науч. трудов, вып. 2, Москва: НИИ Рос. ак. худ-в, с. 59-68.

Гнатенко, П.И., Павленко, В. Н., 1999, Идентичность: Философский и психологический анализ. Киев, 466 с.

Скворцов, А. А., 2015, Этика, Москва: Юрайт, 322 с.

Стоклицкая-Терешкович, В. В., 1960. Основные проблемы истории средневекового города $X-X V$ вв., Москва: Изд-во соц-эк. лит-ры, 350 с.

Харитонович, Д. Э. 1999, Ремесло. Цехи и миф, Город в средневековой циивилизации Западной Европы. Т. 2. Жизнь города и деятельность горожан. Москва: Наука, с. 118-124.

\section{References}

Venecianskij ceh $v$ XIII $-X V v v$. [Venetian guild in the $13^{\text {th }}-15^{\text {th }}$ centuries], 1971. Uch. posobie. Ch.1. Gor'kij: Gor'kovskij gos. un-t, 24 s. (in Russian).

Golovin, V. P., 2000. Ceny na proizvedenija iskusstva v Italii i blagosostojanie hudozhnikov. Ital'janskij sbornik. Sb. nauch. Trudov, vyp. 2, Moskva: NII Ros. ak. hud-v, s. 59-68. (in Russian).

Gnatenko, P. I., Pavlenko, V. N., 1999, Identichnost': Filosofskij i psihologicheskij analiz. [Identity. Philosophical and psychological analysis], Kiev, 466 s. (in Russian).

Skvorcov, A. A., 2015. Jetika [Ethics], Moskva: Jurajt, 2015. 322 s. (in Russian).

Stoklickaja-Tereshkovich, V. V., 1960. Osnovnye problemy istorii srednevekovogo goroda $X-X V v v$. [Central issues in the history of mediaeval town $10^{\text {th }}-15^{\text {th }}$ centuries], Moskva: Izd-vo soc-jek. lit-ry, 350 s. (in Russian).

Haritonovich, D. Je., 1999. Remeslo. Cehi i mif [Handicraft. Guilds and myth], Gorod v srednevekovoj civilizacii Zapadnoj Evropy, $t$. 2, Zhizn' goroda i dejatel'nost' gorozhan, Moskva: Nauka, s. 118-124. (in Russian).

Balestracci, D., 1975 - 76, «Li lavoranti non cognosciuti». Il salariato in una città medievale (Siena 1340 - 1344), Bulletino senese di storia patria, 82-83, pp. 67-157. (in Italian).

Barlucchi, A., 2013. Gli statuti delle arti e la normativa sul mondo del lavoro nella Toscana dei Comuni: sguardo panoramico e prospettive di ricerca, Archivio Storico Italiano, vol. 171, № 3 (637), luglio-settembre 2013, p. 509-541. (in Italian).

Baxandall, M., Painting and Experience in Fifteenth Century Italy, Oxford Unversity Press, 1972, 165 p. (in English).

Bowsky, W. M., 1981. A Medieval Italian Commune: Siena Under the Nine, 1287 - 1355, Univ. of Calif. Press, 1981, 327 p. (in English).

Burke, P., The Italian Renaissance. Culture and Society in Italy, Princeton Univ. Press, 1994, 287 p. (in English).

Carteggio unedito d'artisti dei secoli XIV, XV, XVI, 1840. Pubblicato ed illustrato con documenti pure inediti dal dott. Giovanni Gaye, т. II. Firenze: Molini. (in Italian).

Della Valle, Guglielmo., 1782. Lettere sanesi sopra le belle arti. 3 T. Venezia, Pasquale, 1782, т. I, 292 p. (in Italian). 
Dìaz, P. C., 2001, Monasteries in the peripheral area. Topographies of Power in the Early Middle Ages. Ed. by M.B. de Jong, F.Theuws, C. van Rhijn. BRILL, pp. 329-359. (in English).

Documenti per la storia dell'arte senese, raccolti ed illustrati dal dott. Gaetano Milanesi, 1854. T. I, Secoli XIII e XIV, Siena: O. Porri, 392 p. (in Italian).

Documenti per la storia dei rivolgimenti politici del commune di Siena dal 1354 al 1369, da Giuliano Luchaire, Lyon-Paris, 1906,272 p. (in Italian).

Goldthwaite, R. A., 1982. The Building of Renaissance Florence, John Hopkins University Press, 459 p. (in English)

Kleiner, F. S., 2009. Garder's art through the ages: A Global history. Cengage Learning EMEA, 1088 p. (in English)

Maginnis, H. B. J., 2003. The World of the Early Sienese Painter, Pennsylvania State University Press, 440 p. (in English).

Nicholas, D. M., 2014. The Growth of the Medieval City: From Antiquity to the Early Fourteenth Century, Routledge, 432 p. (in English).

Ross, L., 2003, Artists of the Middle Ages. Greenwood Publishing Group, 182 p. (in English).

Statuti senesi scritti in volgare ne' secoli XIII e XIV, 1863. Per cura di F.-L. Polidori, Bologna, Romagnoli, V. I-II. (in Italian).

Wainwright, V., 1987. The testing of a popular Sienese regime: The «Riformatori» and the insurrections of 1371, I Tatti Studies in the Italian Renaissance, vol. 2, pp. 107-170. (in English).

\title{
SUMMARY
}

\section{ARTISAN AND GUILD IN EARLY ITALIAN RENAISSANCE (CASE OF BREVE OF SIENA ARTISTS GUILD, 1356)}

\author{
Maria Kushnarova \\ Cand. of Sciences (Philosophy), \\ Researcher, V. I. Vernadsky National library of Ukraine, Kyiv
}

The paper offers analysis of Breve (statute) of Siena painters guild, which was drawn up in 1356. The paper contains brief description of the history of the document introducing into scientific circulation. The document elaboration is traced within the context of Siena political history in the $14^{\text {th }}$ century. The hypothesis is that the statute was called to life to make possible for painters to participate in the city elections and governance. The biggest group of the statute articles deals with guild organization, guild leaders' salaries, their status and duties, as well as common members' duties regarding the guild and its executives. Analysis of articles which regulate punishments and fines allows to conclude that Siena painters guild didn't set the standards for artists' productive or commercial activity as well as didn't watch its quality or quantity issues, except couple of isolated cases. The statute mainly dealt with guild members relations somehow concerned with production or professional activity. The guild could be considered as board of professionals to provide every guild member with opportunity to pursue his business with no interference from other guild members. Another point of interest for this board was to take care of the guild reputation because this reputation in its turn, formed every single guild member reputation. The author makes the conclusion that Siena guild of painters performed the functions of certain referent normative group which defined its members' duties via setting ethic norms which the members should to obey in their professional life and communication. The guild was the mean helped to make ones self-identification, and in this way to define his place within the system of social connections.

Keywords: handicraft, guild, statute, city, Siena, painter, Renaissance, Italy. 